\title{
ANGUILLICOLOSIS AMONG SILVER EELS: A 2-YEAR SURVEY IN 4 HABITATS FROM CAMARGUE (RHÔNE DELTA, SOUTH OF FRANCE)
}

\author{
F. LEFEBVRE, A. ACOU, G. POIZAT, A.J. CRIVELLI \\ with the technical collaboration of P. CONTOURNET, F. PRIOUR and O. SOULAS
}

Station Biologique de la Tour du Valat, Le Sambuc, 13200 Arles, France.

\begin{abstract}
We have investigated the spread of the infection by Anguillicola crassus among the silver phase of the European eel Anguilla anguilla in the Rhône delta. We reported values of prevalence, mean intensity and abundance in 4 habitats and we revealed negative relationships between these parasitic parameters and values of salinity (prevalence from $52 \%$ in brackish waters to $77 \%$ in fresh waters). We have also assessed the health state of the infected organ, i.e. the swimbladder. This may be a way to check the parasitic history of individuals throughout their continental phase. In silver eels free from parasites, the proportion of past infected individuals was ranged between $40 \%$ and $78 \%$. When adding individuals showing worms at the autopsy with those showing signs of past infection(s), we highlighted a great proportion of silver eels really affected by anguillicolosis (from $71 \%$ to $95 \%$, with a negative relationship in respect to salinity values). So, considering the spread of the infection, and its potential impairments on body condition, gas exchanges, hydrostatic abilities, etc., one may legitimately question about the proportion of silver eels that may get back to the Sargasso sea and reproduce.
\end{abstract}

Key-words: Anguilla anguilla, Anguillicola crassus, swimbladder, infection, parasite pressure, pathology, spawning migration

\section{L'ANGUILLICOLOSE CHEZ LES ANGUILLES ARGENTÉES : UN SUIVI SUR 2 ANS DANS 4 HABITATS DE CAMARGUE (DELTA DU RHÔNE, SUD DE LA FRANCE)}

\section{RÉSUMÉ}

Nous avons cherché à connaître l'étendue de l'infection par Anguillicola crassus au sein de la fraction argentée de l'anguille européenne Anguilla anguilla dans le delta du Rhône. Nous présentons ici les valeurs de prévalence, d'intensité et d'abondance moyenne dans 4 habitats et nous montrons une relation négative entre ces indices parasitaires et les valeurs de salinité (prévalence de $52 \%$ en eau saumâtre à $77 \%$ en eau douce). Nous avons également estimé l'état de santé de l'organe parasité, à savoir la vessie natatoire. Ce peut être un moyen d'appréhender l'histoire parasitaire des individus au cours de leur phase continentale. Chez les anguilles argentées ne présentant pas de parasites à la dissection, la proportion d'individus qui montre des signes d'infection(s) passée(s) est comprise entre 40 et $78 \%$. Si nous cumulons les individus présentant des parasites à la dissection et ceux montrant des signes d'infection(s) passée(s), nous montrons qu'une importante proportion d'anguilles argentées est 
concernée par l'anguillicolose (entre $71 \%$ et $95 \%$, avec une relation négative par rapport aux valeurs de salinité). Dès lors, considérant l'étendue de l'infection et ses impacts potentiels sur la condition somatique, les échanges gazeux, la régulation hydrostatique, etc., on peut légitimement s'interroger sur la proportion d'anguilles argentées qui pourront effectivement rejoindre la mer des Sargasses et se reproduire.

Mots-clés : Anguilla anguilla, Anguillicola crassus, vessie natatoire, infection, pression parasitaire, pathologie, migration de reproduction

\section{INTRODUCTION}

Since the early 1980s, the European eel Anguilla anguilla (L., 1758) has been affected by a swimbladder parasite, the nematode Anguillicola crassus (KUWAHARA, NIIMI and ITAGAKI, 1974). The parasite was brought into Europe probably as a result of importation of its native host, the Japanese eel Anguilla japonica (PETERS and HARTMANN, 1986). The first case of infection (i.e. anguillicolosis) dates from 1982, in West Germany (NEUMANN, 1985). In France, its presence was first recorded in 1985 in fresh and brackish waters from the Rhône river delta (Camargue, South of France) (DUPONT and PETTER, 1988). Since then, in less than 2 decades, the parasite has colonised nearly all European countries, and North Africa (ASHWORTH and BLANC, 1997, and references therein). Probably as a result of the fear caused by its presence in the European eel stock, the nematode has attracted increasing attention, and numerous papers have dealt with the biology and epidemiology of $A$. crassus (see references in RIGAUD, GARDES and CASTOR, 1994; ACOU, FEUNTEUN and LAMBERT, 1999).

The impact on the physiology, body condition and survival of its host during the continental phase remains the subject of debate (MÖLLER et al., 1991; BARUS and PROKES, 1996; NEMCSÓK et al., 1999; KELLY, KENNEDY and BROWN, 2000), though authors widely accept the idea that $A$. crassus may impair the success of the spawning migration to the Sargasso Sea (KOOPS and HARTMANN, 1987; BOON et al., 1990; SPRENGEL and LÜCHTENBERG, 1991). The main reason put forward is the partial, and sometimes total, degeneration of the swimbladder caused by the migration of the $3^{\text {rd }}$ larval stage through the wall of this organ (HAENEN et al., 1989). The swimbladder is effectively involved in many important functions, including gas exchange and hydrostatic abilities (TESCH, 1989). In eels in continental phase, infection by $A$. crassus was shown to alter the mechanism of gas deposition in the swimbladder (WÜRTZ, TARASCHEWSKI and PELSTER, 1996). For eels that migrate in the deep open sea environment, the role of the swimbladder is obviously reinforced, as revealed by the morphological and histological changes that have to occur at silvering process (i.e. increasing capabilities in gas storage and in gas exchange, KLECKNER, 1980 in A. rostrata; and YAMADA et al., 2001, in A. japonica). To date, no studies have focused on the difficulties in swimming and hydrostatic regulation that silver eels may encounter during their spawning migration. However, a successful transoceanic migration must require a swimbladder in a perfect functional status, when considering the nature of the migration which takes place at a depth of at least $700 \mathrm{~m}$, and includes regular vertical migrations up to the surface (TESCH, 1989; FRICKE and KAESE, 1995).

An additional cost of anguillicolosis could be related to the presence of worms inside the swimbladder (lumen worms). Indeed, the bloodsucking activities of $A$. crassus (from $4^{\text {th }}$ larval stage to adult) may represent a substantial cost for silver eels, at a moment where they stop to feed and when the energy budget is mainly allocated to the reproductive effort. This could have adverse effects by lowering body condition and/or fecundity. Such an impact is strongly supported by the recent work of KIRK, LEWIS and KENNEDY (2000) which demonstrated that $A$. crassus was able to survive and even produce eggs in seawater eels up to 6 months, i.e. an extended period covering almost the entire migration time to the reproductive area (FRICKE and KAESE, 1995). 
To date, a single work has addressed infection among the silver stage of the European eels (NIELSEN, 1997). It described the infection spread in 3 different habitats of Danish waters, and showed that the proportion of infected eels was higher in freshwater $(80 \%)$ than in brackish or sea waters (30\%). This suggests that parasite pressure would be lowered by salinity, but nothing is known concerning the swimbladder health state of the future genitors. There is therefore a need to thoroughly assess the quality of silver eels before the reproductive migration. Throughout this paper, a clear distinction was made between current infection (lumen worms) and past infection(s) (damages to the swimbladder). A total infection rate (signs of current or past infection(s)) was then computed to assess the proportion of silver eels really affected by anguillicolosis. Data were collected in 4 habitats in the Rhône delta, giving thus the opportunity to test the effect of salinity on parasite pressure. Results are discussed in regard to the success of the spawning migration and its reproductive output.

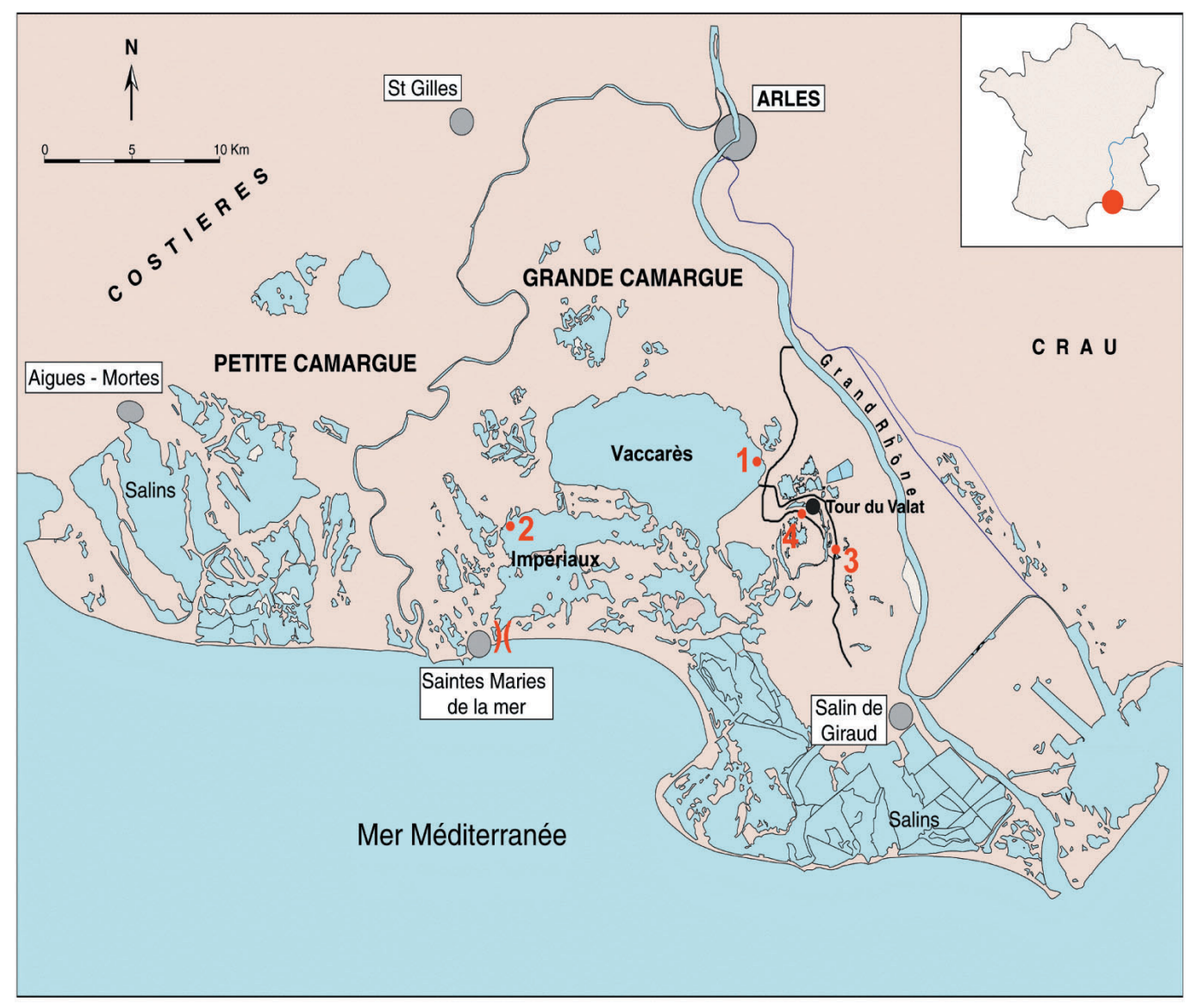

\section{Figure 1}

Geographical situation of the study area and localisation of the sampling sites. 1-Capelière, 2-Malagroy, 3-Fumemorte, 4-Aube de Bouic. The symbol )( indicates the single exit way for silver eels (Grau de la Fourcade, Saintes Maries de la Mer).

\section{Figure 1}

Situation géographique de la zone d'étude et localisation des stations d'échantillonnage. 1-Capelière, 2-Malagroy, 3-Fumemorte, 4-Aube de Bouic. Le symbole )( indique l'unique voie de sortie des anguilles argentées (Grau de la Fourcade, Saintes Maries de la Mer). 


\section{MATERIALS AND METHODS}

Eels were sampled at 4 sites in the Rhône delta (Camargue, South of France; see Figure 1). The Aube de Bouic is a dead-end canal (for rice-field irrigation) with a single connection with the river Rhône. The entry of freshwater is controlled by a pumping station located approximately $33 \mathrm{~km}$ upstream of the mouth of the river Rhône. It was shown that glass eels and larger eels can survive passage through the pump (POIZAT et al., 1999). The sampling site was located at $10 \mathrm{~km}$ downstream the pump (mean salinity $=0 \mathrm{~g} / \mathrm{l}$ ). The Fumemorte is a drainage canal that collects rice-field waters before flowing into the Vaccarès lagoon. Thus, the Fumemorte canal is under the dual influence of freshwaters from the river Rhône (through many irrigation canals), and brackish waters that enter the drainage system by the Vaccarès lagoon. The sampling site was located approximately $7 \mathrm{~km}$ upstream of the lagoon (mean salinity $=0.8 \mathrm{~g} / \mathrm{l}$ ). The remaining sampling sites were located in lagoons: at the Capelière in the Vaccarès lagoon $(6400$ ha, mean salinity $=10.8 \mathrm{~g} / \mathrm{l})$ and at the Malagroy in the Impériaux lagoon (4600 ha, mean salinity $=26.7 \mathrm{~g} / \mathrm{l})$.

Monthly samplings were conducted over 2 consecutive years, from January 1998 to December 1999 (in 1999, only 6 months were sampled in Capelière and in Malagroy: April, May, June, September, October, November). In each site, a fyke net with a $6 \mathrm{~mm}$ mesh in the funnel was used. The nets were set on 4 consecutive days per month and visited every 24 hours. Eels were frozen on the day of capture and examined later.

The total length (TL) was recorded to the nearest $1 \mathrm{~mm}$. The vertical $\left(D_{v}\right)$ and horizontal $\left(D_{h}\right)$ eye diameters were measured with calliper to the nearest $0.1 \mathrm{~mm}$. An Ocular Index (OI), based on the relationship between the size of the eyes and the total length, was calculated according to the following formula: $\left(\left(D_{v}+D_{h}\right) / 4\right)^{2} \times(\pi / T L)$. Only those eels that met the threshold value for silvering, i.e. OI $\geq 6.5$ (PANKHURST, 1982), were considered in this study.

The sex was macroscopically determined by examining the shape and size of the gonads (SINHA and JONES, 1966). The swimbladder was removed and examined macroscopically for the presence of Anguillicola crassus. The number of living lumen worms (inside the swimbladder) was recorded. Epidemiology of anguillicolosis was described using the conventional terms of prevalence, mean intensity and mean abundance, as defined by BUSH et al., (1997). The prevalence is the proportion of infected host in a sample (\%). The mean intensity is the average number of parasites per infected hosts in a sample. The mean abundance is the average number of parasites per examined hosts (infected or not) in a sample. This last term is a population parameter that integrates values of both prevalence and mean intensity and, for this reason, it will be used as a measure of current infection.

The health state of the swimbladder was assessed for eels having no parasite at the autopsy. Assessment was made by using the opacity and thickness criteria of the wall swimbladder (MOLNÁR et al., 1993). The swimbladder was then assigned to one of these 2 categories : normal (transparent and thin wall), or damaged (smoke-like opacity and thick wall). Since, experimental investigations have shown that macroscopic changes in the wall swimbladder can only be observed after multiple infection events (WÜRTZ et TARASCHEWSKI, 2000), the health state of the swimbladder will be used as a measure of past infection(s). The proportion of silver eels, free from lumen parasites, but showing signs of past infection(s) was given for each sampling site. Then, the proportion of individuals showing signs of past or current infection(s), (i.e. damages or lumen worms in the swimbladder) was computed for each sampling site. It corresponds to the proportion of silver eels really affected by anguillicolosis and will be refer to actual infection.

As a preliminary analysis, the main biological characteristics of silver eels (sexratio, mean TL in male and mean TL in female) were described according to site and year. This was intended to check the existence of distinct ecotypes of eels in the Rhône delta (i.e. brackish ecotype vs freshwater ecotype) (see PANFILI et XIMÉNĖS, 1994; 
ACOU et al., this issue). The epidemiology of the infection (in terms of current infection, past infection and actual infection) was then compared between sites and analysed in relation to the corresponding salinity values.

However, as in vertebrates, and fishes in particular, sex, size or age of the hosts may influence the intensity of parasitic infection (POULIN, 2000), the existence of distinct ecotypes had to be taken into account in further analyses. For each of the above 3 measures of parasite pressure the effects of year, sex, salinity and TL were explored by performing a Generalised Linear Model (STATISTICA 5.5). Such a method allows to check simultaneously the individual contribution of various factors (continuous or not) in explaining the observed variation in a dependent variable (continuous or not) (BURNHAM and ANDERSON, 1998). Herein, year $(1998,1999)$ and sex (male, female) were entered as categorical factors, and TL and mean salinity at the 4 sites as continuous factors. The goodness of fit for models was accepted when the ratio of the model deviance to its degree of freedom was close to unity (BURNHAM and ANDERSON, 1998). In case of current infection, the dependent variable (abundance, i.e. the number of parasites per eel) was fitted by a normal distribution after log-transformation $(\ln x+1)$, and an identitylink function was used. In other cases, the dependent variables were binomial (0 or 1$)$ and a logit-link function was used. The contribution of terms (mains effects and interactions) to a given model was expressed using the type III likelihood-ratio statistics (Chi-square value, $\chi^{2}$ ). The real effect of salinity was then assessed regarding the sign and the magnitude of the slope in the estimate values.

\section{RESULTS}

\section{Table I}

Epidemiological data at the 4 study sites (Malagroy, Capelière, Fumemorte, Aube de Bouic) with details on sample size ( $n$ ) and eel length (TL, in $\mathrm{mm}$ ) in relation to year and sex. Means are given $\pm \mathrm{SE}$.

\section{Tableau I}

Données épidémiologiques aux 4 sites d'études (Malagroy, Capelière, Fumemorte, Aube de Bouic) avec détails sur la taille de l'échantillon ( $n$ ) et la longueur des anguilles ( $T L$, en $\mathrm{mm}$ ) en relation avec l'année et le sexe. Les moyennes sont données \pm ES.

\begin{tabular}{|c|c|c|c|c|c|c|c|c|}
\hline & \multicolumn{4}{|c|}{ Malagroy } & \multicolumn{4}{|c|}{ Capelière } \\
\hline & \multicolumn{2}{|c|}{1998} & \multicolumn{2}{|l|}{1999} & \multicolumn{2}{|l|}{1998} & \multicolumn{2}{|l|}{1999} \\
\hline & o & q & $\hat{0}$ & q & o & q & 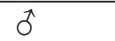 & q \\
\hline $\mathrm{n}$ & 3 & 0 & 15 & 3 & 67 & 17 & 27 & 9 \\
\hline TL & 364.67 & - & 356.47 & 446.33 & 372.58 & 571.18 & 370.26 & 565.00 \\
\hline & \pm 6.94 & - & \pm 7.12 & \pm 72.16 & \pm 3.49 & \pm 11.34 & \pm 4.40 & \pm 20.59 \\
\hline prevalence & 33.33 & - & 53.33 & 66.67 & 65.67 & 64.71 & 66.67 & 55.56 \\
\hline mean & 3.00 & - & 3.38 & 4.50 & 5.34 & 5.64 & 6.89 & 4.20 \\
\hline intensity & - & - & \pm 0.86 & \pm 1.50 & \pm 0.77 & \pm 2.15 & \pm 3.01 & \pm 1.77 \\
\hline mean & 1.00 & - & 1.80 & 3.00 & 3.51 & 3.65 & 4.59 & 2.33 \\
\hline abundance & \pm 1.00 & - & \pm 0.63 & \pm 1.73 & \pm 0.59 & \pm 1.52 & \pm 2.09 & \pm 1.19 \\
\hline
\end{tabular}

\begin{tabular}{|c|c|c|c|c|c|c|c|c|}
\hline & \multicolumn{4}{|c|}{ Fumemorte } & \multicolumn{4}{|c|}{ Aube de Bouic } \\
\hline & \multicolumn{2}{|c|}{1998} & \multicolumn{2}{|l|}{1999} & \multicolumn{2}{|c|}{1998} & \multicolumn{2}{|l|}{1999} \\
\hline & 0 & q & $0^{+}$ & q & 0 & $q$ & 0 & $q$ \\
\hline $\mathrm{n}$ & 4 & 11 & 23 & 118 & 2 & 19 & 1 & 17 \\
\hline$\overline{T L}$ & 396.75 & 606.09 & 393.35 & 582.98 & 386.00 & 629.47 & 361.00 & 621.41 \\
\hline & \pm 10.05 & \pm 26.32 & \pm 7.75 & \pm 7.98 & \pm 5.00 & \pm 19.68 & - & \pm 16.71 \\
\hline prevalence & 100.00 & 90.91 & 86.96 & 66.10 & 50.00 & 78.95 & 100.00 & 76.47 \\
\hline mean & 10.00 & 15.60 & 5.90 & 7.45 & 24.00 & 10.67 & 6.00 & 7.23 \\
\hline intensity & \pm 1.08 & \pm 9.36 & \pm 0.96 & \pm 1.00 & - & \pm 2.99 & - & \pm 1.53 \\
\hline mean & 10.00 & 14.18 & 5.13 & 4.92 & 12.00 & 8.42 & 6.00 & 5.53 \\
\hline abundance & \pm 1.08 & \pm 8.59 & \pm 0.93 & \pm 0.74 & \pm 12.00 & \pm 2.56 & - & \pm 1.39 \\
\hline
\end{tabular}


For the 2 years and the 4 sites, a total of 336 eels met the PANKHURST threshold value for the silver stage $(\mathrm{OI} \geq 6.5)$. Details on annual sample size, sex-ratio and total length are given by site in Table I. There was no significant difference in sexratio between years within any one site (Mann et Whitney tests: $p>0.32$ ). There was a significant difference in sex-ratio between sites (Kruskal-Wallis test: $H_{[3,336]}=138.73, p$ $<0.001)$. Sex-ratio was male-biased with a significant departure from unity in Capelière (78.3\%, 94 males and 26 females, observed vs expected frequencies: $\chi^{2}=38.53$, df $=$ $1, \mathrm{p}<0.001)$ and in Malagroy $\left(85.7 \%, 18\right.$ males and 3 females, $\chi^{2}=10.71$, df $=1, p$ $<0.01)$, but female-biased in Fumemorte (17.3\%, 27 males and 129 females; $\chi^{2}=$ 66.69, df $=1, p<0.001)$ and in Aube de Bouic $\left(7.7 \%, 3\right.$ males and 36 females, $\chi^{2}=$ 33.46; $d f=1 \mathrm{p}<0.001$ ).

Males showed no difference in size between years within any one site (Mann et Whitney tests: $p>0.22$ ), but significant difference was revealed between sites (KruskalWallis test: $\left.H_{[3,142]}=13.63, p<0.05\right)$. Males were longer in Aube de Bouic $(378 \pm 9 \mathrm{~mm})$ and in Fumemorte $(394 \pm 7 \mathrm{~mm})$, than in Capelière $(372 \pm 3 \mathrm{~mm})$ and in Malagroy $(358 \pm 6$ $\mathrm{mm}$ ). The same was true for females (Kruskal-Wallis tests between years within site: $p$ $>0.31$; Kruskal-Wallis test on site: $\mathrm{H}[3,194]=11.18, \mathrm{p}<0.05)$. Females were longer in Aube de Bouic $(626 \pm 13 \mathrm{~mm})$ and in Fumemorte $(585 \pm 8 \mathrm{~mm})$, than in Capelière $(569 \pm 10$ $\mathrm{mm})$ and in Malagroy $(446 \pm 72 \mathrm{~mm})$.

These results thus confirmed the existence of 2 ecotypes of eels in the Rhône delta: a brackish ecotype (in Malagroy and in Capelière) characterised by male-biased sex ratios and small sizes at silvering, and a freshwater ecotype characterised by female-biased sex ratios and large sizes at silvering (in Fumemorte and in Aube de Bouic).

\section{Current infection: lumen worms}

For each site, prevalence did not differ between years (Mann et Whitney tests: $p$ $>0.05$ ) (see Table I). Annual mean intensities were also similar (Mann et Whitney tests: $p>0.14)$. However, when using mean abundance, there was inter-annual difference in Fumemorte for which 1998 showed particular high parasite burden (13.06 \pm 6.24 vs 4.96 \pm 0.64 ; Mann et Whitney test: $U=637, p<0.05$ ).

There was no difference in prevalence values between the 4 sites (Malagroy: $52.4 \%, n=21$; Capelière: $65.0 \%, n=120$; Fumemorte: $71.8 \%, n=156$; Aube de Bouic: $76.9 \%, n=39$; Kruskal-Wallis test: $\left.H_{[3,336]}=5.27, p=0.15\right)$. Significant difference was observed for mean intensity (Kruskal-Wallis test: $H_{[3,231]}=10.78, p<0.05$ ) and, to summarise, results are presented in Figure 2 for mean abundance (Malagroy: 1.86 $\pm 0.52, n=21$; Capelière: $3.68 \pm 0.61, n=120$; Fumemorte: $5.74 \pm 0.84, n=156$; Aube de Bouic: $7.28 \pm 1.46, n=39$; Kruskal-Wallis test: $\left.H_{[3,336]}=13.36, p<0.01\right)$. There was a negative correlation between parasite abundance and the value of salinity at the fishing site $(R$ Spearman $=-0.20, n=336, p<0.001)$.

The relative contribution of salinity was then assessed in a model also integrating other factors that may potentially influence parasite numbers (i.e. year, sex, TL; see Table Ila). Results confirmed the significant effect of salinity on parasite abundance $\left(\chi^{2}=11.81\right.$, $\mathrm{df}=1, \mathrm{p}<0.001)$. The higher the salinity value, the lower the parasite burden by lumen A. crassus (intercept $=1.35, p<0.001$; slope $=-0.03, p<0.001$ ). Results for presence/absence data or parasite intensity were not presented herein, but supported similar trends. 


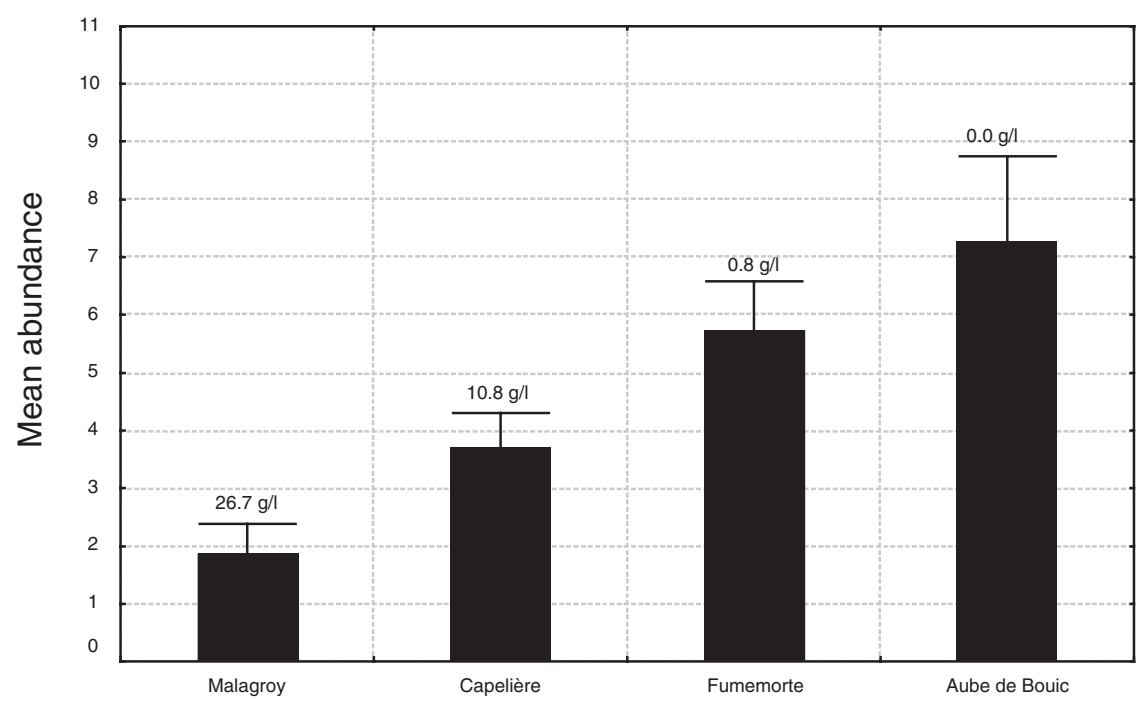

\section{Figure 2}

Mean abundance ( \pm SE) of Anguillicola crassus in relation to the sampling site. Salinity values are given above bars.

\section{Figure 2}

\section{Abondance moyenne ( \pm ES) d'Anguillicola crassus par site d'échantillonnage.} Les valeurs de salinité sont indiquées au-dessus des histogrammes.

\section{Past infection(s): swimbladder health state}

Among those silver eels having no parasite at the autopsy, the proportion of individuals with a damaged swimbladder was relatively high (Malagroy: $40.0 \%, n=10$; Capelière: $69.0 \%, n=42$; Fumemorte: $40.9 \%, n=44$; Aube de Bouic: $77.8 \%, n=9$ ) (Figure 3). There existed a significant difference between sampling sites (Kruskal-Wallis test: $\left.\mathrm{H}_{[3,105]}=9.59, \mathrm{p}<0.05\right)$, but no evident relationship with values of salinity $(\mathrm{R}$ Spearman $=0.06, n=105, p=0.53$ ).

In a global analysis by GLM (Table IIb), salinity showed a marginal influence on the damages caused to the swimbladder $\left(\chi^{2}=0.42\right.$, df $\left.=1, p=0.52\right)$. Only year had significant effect on the health state of the swimbladder $\left(\chi^{2}=33.12\right.$, df $\left.=1, p<0.001\right)$. This may reveal a real year effect, as well as a bias in the course of the study since assessments of the damages to the swimbladder were performed by a different person in 1998 and in 1999.

\section{Actual infection(s): past and current infection(s)}

When adding currently and previously infected individuals, it appeared that the proportion of silver eels affected by anguillicolosis was high whatever the site (Malagroy: $(11+4)^{*} 100 / 21=71.4 \%$; Capelière: $(78+29)^{*} 100 / 120=89.2 \%$; Fumemorte: $(112+18)^{*} 100 / 156=83.3 \%$; Aube de Bouic: $\left.(30+7)^{*} 100 / 39=94.9 \%\right)$ (Figure 4). There was significant difference between sampling sites (Kruskal-Wallis test: $\mathrm{H}_{[3,336]}=8.16, p<$ 0.05 ), but no evident relationship with value of salinity ( $R$ Spearman $=-0.04, n=336$, $\mathrm{p}=0.43)$.

However, in global analysis by GLM (Table IIc), both year and salinity showed significant effect on the index of actual infection (year: $\chi^{2}=26.58$, df $=1, p<0.001$; salinity: $\left.\chi^{2}=4.04, \mathrm{df}=1, \mathrm{p}<0.05\right)$. The higher the salinity value, the lower the probability to be affected by $A$. crassus (intercept $=2.65, p<0.05$; slope $=-0.05, p<0.05$ ). 


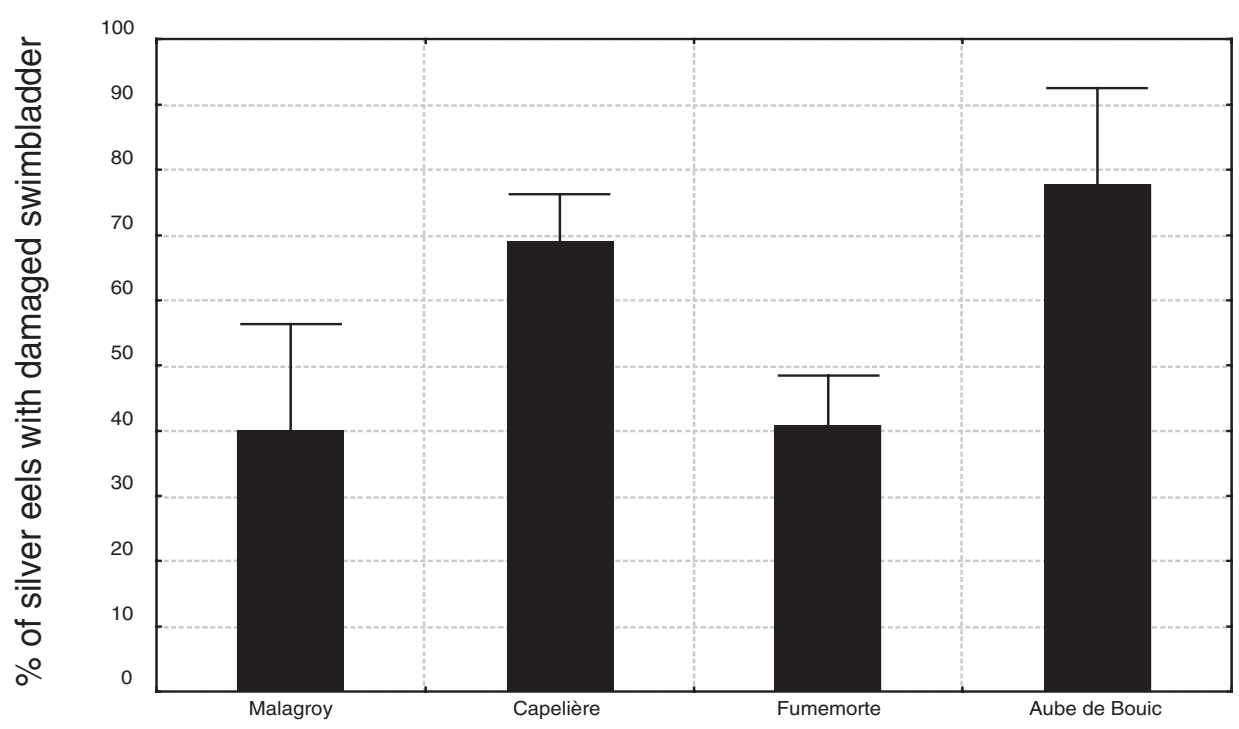

Figure 3

Proportion of silver eels with a damaged swimbladder (among those having no lumen worms at the autopsy). Results are given according to the sampling site (mean $\pm \mathrm{SE})$.

Figure 3

Proportion d'anguilles argentées avec une vessie natatoire dégradée (parmi celles ne présentant pas de parasites à la dissection). Les résultats sont donnés par site d'échantillonnage (moyenne \pm ES).

Table II

Relative contribution of terms to the models: (a) abundance in lumen worms, (b) occurrence of silver eels with a damaged swimbladder, (c) occurrence of silver eels affected by anguillicolosis (showing lumen worms or damaged swimbladder). $\chi^{2}$ values are based on type III likelihood-ratio tests.

Tableau II

Contribution relative des termes aux modèles : (a) abondance des vers dans la vessie natatoire, (b) occurrence des anguilles argentées avec une vessie natatoire endommagée, (c) occurrence des anguilles argentées concernées par l'anguillicolose (présentant des vers ou une vessie natatoire endommagée). Les valeurs de $\chi^{2}$ sont basées sur des tests de likelihood-ratio type III.

\begin{tabular}{lllll} 
& terms & df & $\chi^{2}$ & $p$ \\
\hline & salinity & 1 & 11.81 & $<0.001$ \\
(a) & TL & 1 & 1.27 & 0.26 \\
& year & 1 & 1.11 & 0.29 \\
& sex & 1 & 1.57 & 0.21 \\
& year*sex & 1 & 2.11 & 0.15 \\
\hline & salinity & 1 & 0.42 & 0.52 \\
& TL & 1 & 0.51 & 0.48 \\
(b) & year & 1 & 33.12 & $<0.001$ \\
& sex & 1 & 0.10 & 0.92 \\
& year*sex & 1 & 2.94 & 0.09 \\
\hline & salinity & 1 & 4.04 & $<0.05$ \\
& TL & 1 & 0.04 & 0.83 \\
(c) & year & 1 & 26.58 & $<0.001$ \\
& sex & 1 & 1.61 & 0.20 \\
& year*sex & 1 & 0.94 & 0.33 \\
\hline
\end{tabular}




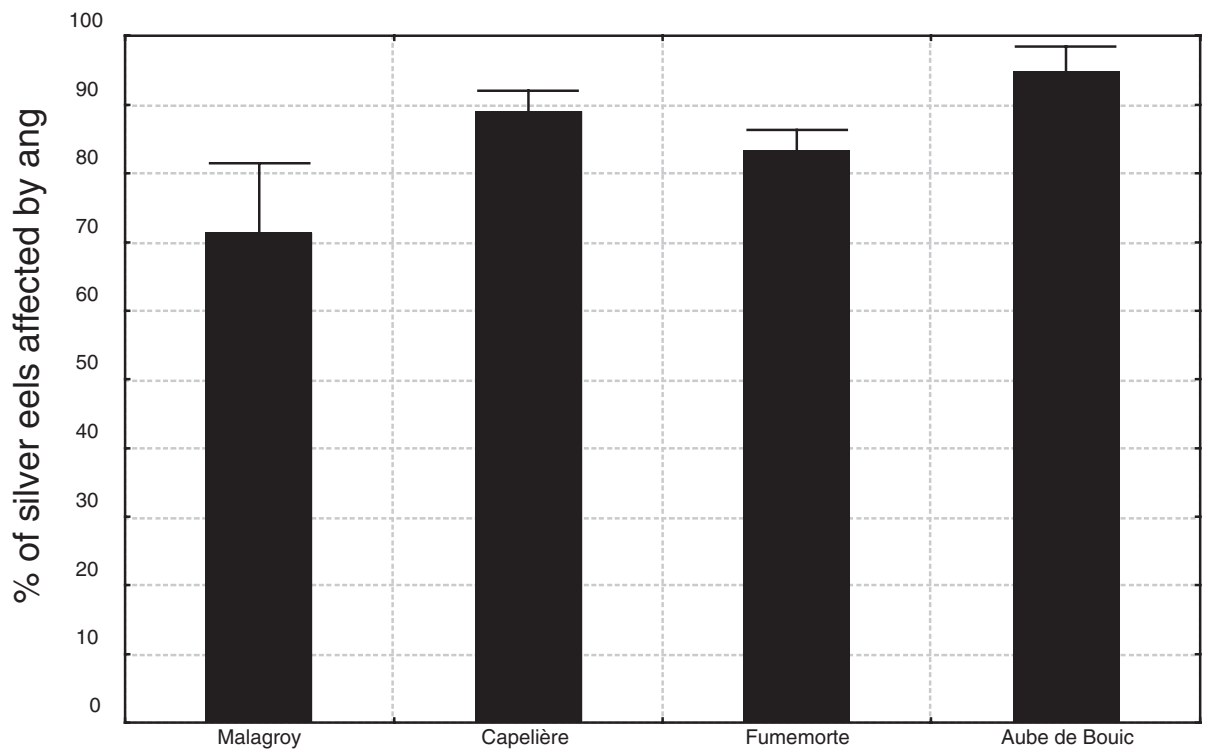

\section{Figure 4}

Proportion of silver eels affected by anguillicolosis (showing lumen worms or signs of past infecton(s)). Results are given according to the sampling site (mean $\pm \mathrm{SE})$.

\section{Figure 4}

Proportion d'anguilles argentées concernée par l'anguillicolose (présence de parasites à la dissection ou signes d'infection(s) passée(s)). Les résultats sont donnés par site d'échantillonnage (moyenne \pm ES).

\section{DISCUSSION}

More than 15 years after the first mention of Anguillicola crassus in the Rhône delta (DUPONT and PETTER, 1988), we report herein values of prevalence ranging from $52 \%$ to $77 \%$ among the silver stage of the European eel. We found a negative correlation between the parasite abundance in a site and the corresponding salinity values $(R=-0.20)$. However, the existence of 2 distinct ecotypes of eels (a brackish water ecotype in Malagroy and in Capelière, and a fresh water ecotype in Fumemorte and in Aube de Bouic) may alter the above relationship. When controlling for sex, year and size effects, we still showed a pronounced salinity influence on parasite abundance. Silver eels thus suffer lower parasite burden in brackish waters than in fresh waters (slope = -0.03). In accordance with NIELSEN (1997), we think this could be explained by the fact that the life cycle of $A$. crassus is primary related to fresh water (DE CHARLEROY et al., 1989).

Among silver eels having no parasite at the autopsy, the proportion of individual with signs of past infection(s) in the swimbladder was ranged from $40 \%$ to $78 \%$. Contrary to what observed for current infection, we found no obvious correlation with values of salinity in this case. The model approach confirms the marginal influence of salinity, but revealed a strong year effect. We think this had to be related to a yearly change in the person that has recorded the damages in the swimbladder. To some extent, this emphasises the necessity to define and use more precise and objective criteria in the assessment of swimbladder health state (see LEFEBVRE, CONTOURNET and CRIVELLI, 2002). 
When adding currently and previously infected individuals, it appeared that the proportion of silver eels really affected by anguillicolosis was relatively high (Malagroy: $71 \%$, Capelière: $89 \%$, Fumemorte: $83 \%$, Aube de Bouic: $95 \%$ ). Other things being equal, there still exists a significant negative relationship between the parasite pressure and values of salinity (slope $=-0.05$ ). However, whatever the habitat, this is thus up to $70 \%$ of the silver phase that shows signs of past infection(s) or current infection. In addition, needless to say that we certainly underestimated the real parasite pressure as we did not take into account the larval stages, that may represent two-third of the total parasite number (according to THOMAS and OLLEVIER, 1992). So, this is the great majority of future genitors that may encounter potential difficulties during their $6000 \mathrm{~km}$ transoceanic migration and in their spawning site.

In their investigation in deep sea and hyperbaric caisson, FONTAINE et al. (1990) have not demonstrated clear-cut incidence of the infection on the survival of silver eels. However, the sample size was small and authors have not considered the health state of the swimbladder. The degeneration of the swimbladder is certainly the most serious impact caused by the parasite. SCHAEFER, LEHMANN and MOCK (1999) reported that $25 \%$ of their infected individuals (elver eels) showed a presumably irreversible damage of the swimbladder. Among our sample, we have estimated to approximately $20 \%$ the proportion of individuals having a totally degenerated swimbladder, i.e. few if any lumen left (data not shown). For these eels, one can legitimately question about their chance to get back to the Sargasso sea and reproduce.

The first report for decreasing capture in eels (late 70's; MORIARTY, 1990) took place before the first mention of Anguillicola crassus in the European eel stock (early 80 's), and so, the parasite cannot be the origin of the decline. Nevertheless, there is no doubt that anguillicolosis now constitutes an additional threat for the species.

\section{ACKNOWLEDGEMENTS}

We thank Anna SALTMARSH for comments and English corrections throughout the manuscript. This research was supported by the Foundation Tour du Valat.

\section{REFERENCES}

ACOU A., FEUNTEUN E., LAMBERT P., 1999. Recueil de références bibliographiques européennes concernant l'anguille (Anguilla anguilla L.) sur la période 1994-1998. CEMAGREF Bordeaux, Groupe National Anguille, 73 p.

ASHWORTH S.T., BLANC G., 1997. Anguillicola crassus, un colonisateur agressif récemment introduit dans les stocks Européens d'anguilles. Bull. Fr. Pêche Piscic., 344/345, 335-342.

BARUŠ V., PROKEŠ M., 1996. Length-weight relations of uninfected and infected eels (Anguilla anguilla) by Anguillicola crassus (Nematoda). Folia Zool., 45, 183-189.

BOON J.H., CANNERTS V.M.H., AUGUSTIJN H., MACHIELS M.A.M., DE CHARLEROY D., OLLEVIER F., 1990. The effect of different infection levels with infective larvae of Anguillicola crassus on haematological parameters of European eel (Anguilla anguilla). Aquaculture, 87, 243-253.

BURNHAM K.P. and ANDERSON D.R., 1998. Model selection and inference: a practical information-theoric approach. Springer, New York.

BUSH A.O., LAFFERTY K.D., LOTZ J.M., SHOSTAK A.W., 1997. Parasitology meets ecology on its own terms: Margolis et al revisited. J. Parasitol., 83, 575-583.

DE CHARLEROY D., THOMAS K., BELPAIRE C., OLLEVIER F., 1989. The variability of the free living larvae of Anguillicola crassus. J. Appl. Ichthyol., 5, 154-156. 
DUPONT F., PETTER A.J., 1988. Anguillicola, une épizootie plurispécifique en Europe : apparition de Anguillicola crassa (Nematoda, Anguillicolidae) chez l'anguille européenne Anguilla anguilla en Camargue, sud de la France. Bull. Fr. Pêche Piscic., 308, 38-41.

FONTAINE T.A., LE BELLE N., LOPEZ E., QUERAT B., VIDAL B., BARTHELEMY L., SEBERT P., ALINAT J., PETTER A.J., 1990. Infestation de populations françaises d'anguilles (Anguilla anguilla L.) par des nématodes (Anguillicola crassus) : essais thérapeutiques, évaluations de risques potentiels liés à l'écophysiologie de l'hôte. Ann. Parasitol. Hum. Comp., 65, 64-68.

FRICKE H., KAESE R., 1995. Tracking of artificially matured eels (Anguilla anguilla) in the Sargasso Sea and the problem of the eel's spawning site. Naturwissenschaften, 82 , 32-36.

HAENEN O.L.M., GRISEZ L., DE CHARLEROY D., BELPAIRE C., OLLEVIER F., 1989. Experimentally induced infections of the European eel, Anguilla anguilla L., with Anguillicola crassus (Nematoda, Dracunculoidea) and subsequent migration of the larvae. Dis. Aquat. Org., 7, 97-101.

KELLY C.E., KENNEDY C.R., BROWN J.A., 2000. Physiological status of wild European eels (Anguilla anguilla) infected with the parasitic nematode, Anguillicola crassus. Parasitology, 120, 195-202.

KIRK R.S., LEWIS J.W., KENNEDY C.R., 2000. Survival and transmission of Anguillicola crassus Kuwahara, Niimi and Itagaki, 1974 (Nematoda) in seawater eels. Parasitology, 120, 289-295.

KLECKNER R.C., 1980. Swim bladder volume maintenance related to initial oceanic migratory depth in silver-phase Anguilla rostrata. Science, 208, 1481-1482.

KOOPS H., HARTMANN F., 1987. Infection of eels from different regions with Anguillicola. Working Party on Eels, EIFAC, Bristol (U.K.), April 1987, 7p.

KUWAHARA A., NIIMI A., ITAGAKI H., 1974. Studies of a nematode parasite in the air bladder of the eel. I. Description of Anguillicola crassa n. sp. (Philometridae, Anguillicolidae). Jap. J. Parasitol., 23, 275-279.

LEFEBVRE F., CONTOURNET P., CRIVELLI A.J., 2002. The health state of the eel swimbladder as a measure of parasite pressure by Anguillicola crassus. Parasitology, 124, 457-463.

MÖLLER H., HOLST S., LÜCHTENBERG H., PETERSEN F., 1991. Infection of eel Anguilla anguilla from the River Elbe estuary with two nematodes, Anguillicola crassus and Pseudoterranova decipiens. Dis. Aquat. Org., 11, 193-199.

MOLNÁR K., BASKA F., CSABA G., GLÀVITS R., SZÉKELI C., 1993. Pathological and histopathological studies of the swimbladder of eels Anguilla anguilla infected by Anguillicola crassus (Nematoda: Dracunculoidea). Dis. Aquat. Org., 15, 41-50.

MORIARTY C., 1990. European catches of Elver of 1928-1988. Int. Revue ges. Hydrobiol., 75, 701-706.

NEMCSÓK J., BÁLINT T., FAZAKAS J., KÀTAI F., KISS I., LE HUU HIEU, KUFCSÀK O., LÀNG G., POLYHOS C., SZABÓ I., SZEGLETES T., 1999. The contribution of a pyrethroid insecticide to the massive eel (Anguilla anguilla) devastation, in Lake Balaton, in 1995. Acta Biol. Hung., 50, 161-173.

NEUMANN W., 1985. Schwimmblasenparasit Anguillicola bei Aalen. Fischer and Teichwirt, 36, 322.

NIELSEN M.E., 1997. Infection status of the swimbladder worm, Anguillicola crassus, in silver stage European eel, Anguilla anguilla, from three different habitats in Danish waters. J. Appl. Ichthyol., 13, 195-196.

PANFILI J., XIMÉNĖS M.C., 1994. Evaluation de l'âge et de la croissance de l'anguille européenne (Anguilla anguilla L.) en milieu continental: méthodologies, validation, application en Méditerranée et comparaisons en Europe. Bull. Fr. Pêche Piscic., 335, 43-66. 
PANKHURST N.W., 1982. Relation of visual changes to the onset of sexual maturation in the European eel Anguilla anguilla (L.). J. Fish Biol., 21, 127-140.

PETERS G., HARTMANN F., 1986. Anguillicola, a parasitic Nematode of the swimbladder spreading among eel populations in Europe. Dis. Aquat. Org., 1, 229-230.

POIZAT G., CHAUVELON P., ROSECCHI E., CRIVELLI A.J., 1999. Passage de poissons du Rhône par les pompes d'irrigation de camargue : premiers résultats. Bull. Fr. Pêche Piscic., 352, 31-43.

POULIN R., 2000. Variation in the intraspecific relationship between fish length and intensity of parasitic infection: biological and statistical causes. J. Fish Biol., 56, 123-137.

RIGAUD C., GARDES C., CASTOR N., 1994. Recueil de références bibliographiques françaises concernant l'anguille (Anguilla anguilla L.) sur la période 1987-1994. Bull. Fr. Pêche Piscic., 335, 297-317.

SCHAEFER J.-W., LEHMANN J., MOCK D., 1999. Untersuchungen zum paratenischen Wirt des Schwimmblasenwurms Anguillicola crassus in North-Rhine Westfalia, in WEDEKIND H., Krankheiten der aquatischen Organismen, 23-30, Gross Glienicke, FRG.

SINHA V.P.R., JONES W., 1966. On the sex and distribution of the freshwater eel (Anguilla anguilla). J. Zool. Lond., 150, 371-385.

SPRENGEL G., LÜCHTENBERG H., 1991. Infection by endoparasites reduces swimming speed of European smelt Osmerus eperlanus and European eel Anguilla anguilla. Dis. Aquat. Org., 11, 31-35.

TESCH F.-W., 1989. Changes in swimming depth and direction of silver eels (Anguilla anguilla L.) from continental shelf to deep sea. Aquat. Living Resour., 2, 9-20.

THOMAS K., OLLEVIER F., 1992. Paratenic hosts of the swimbladder nematode Anguillicola crassus. Dis. Aquat. Org., 13, 165-174.

WÜRTZ J., TARASCHEWSKI H., PELSTER B., 1996. Changes in gas composition in the swimbladder of the European eel (Anguilla anguilla) infected with Anguillicola crassus (Nematoda). Parasitology, 112, 233-238.

WÜRTZ J., TARASCHEWSKI H., 2000. Histopathological changes in the swimbladder wall of the European eel Anguilla anguilla due to infections with Anguillicola crassus. Dis. Aquat. Org., 39, 121-134.

YAMADA Y., ZHANG H., OKAMURA A., TANARA S., HORIE N., MIKAWA N., UTOH T., OKA H. P., 2001. Morphological and histological changes in the swimbladder during maturation of the Japanese eel. J. Fish Biol., 58, 804-814. 